$\begin{array}{llllllllllllllll}\mathrm{S} & \mathrm{T} & \mathrm{U} & \mathrm{D} & \mathrm{I} & \mathrm{A} & \mathrm{I} & \mathrm{M} & \mathrm{A} & \mathrm{T} & \mathrm{E} & \mathrm{R} & \mathrm{I} & \mathrm{A} & \mathrm{L} & \mathrm{Y}\end{array}$

Przeszłość Demograficzna Polski 40 (2018)

Poland's Demographic Past 40 (2018)

DOI: $10.18276 /$ pdp.2018.40-02

Iryna Voronchuk

ORCID: https://orcid.org/0000-0001-5466-5356

Research Institute of Ukrainian Studies, Kyiv

email:voronchuk@ukr.net

\title{
Volhynian Court Books as a Source for Studying the History of the Ukrainian Noble (Szlachta) Family in the $16^{\text {th }}$ and $17^{\text {th }}$ Centuries
}

\author{
Wołyńskie księgi sądowe jako źródło do badań \\ nad historią ukraińskiej rodziny szlacheckiej w XVI-XVII stuleciu
}

\begin{abstract}
The article documents the importance and significance of castle and land court books for studying the history of the early modern Ukrainian family, many aspects of which so far have hardly been explored. An overview of the history and the content of Volhynian court books is provided, and the documents that contain information on contemporary families are detailed and analyzed. The court books are shown to represent a comprehensive and valuable source that helps reconstruct single and extended family structures, identify kin relations, characterize demographic behaviour, and study intra-family relationships. The analysis of the court books suggests that some stereotypes about the
\end{abstract}

\begin{abstract}
Abstrakt
W artykule zaprezentowano znaczenie sądowych ksiąg grodzkich i ziemskich, pod wieloma względami niezadawalająco przebadanych, dla badań nad wczesnonowożytną rodziną ukraińską. Przedstawiono w nim przegląd dziejów i zawartości ksiąg sądowych z obszaru Wołynia, poddając szczegółowej analizie dokumenty zawierające informacje o ówczesnych rodzinach. Wykazano, że księgi sądowe stanowią wszechstronne i cenne źródło, które pomaga rekonstruować proste i rozszerzone struktury rodzinne, identyfikować stosunki międzyludzkie, charakteryzować zachowania demograficzne i badać relacje wewnątrz rodziny. Analiza ksiąg sądowych sugeruje, że niektóre stereotypy
\end{abstract}


early modern Ukrainian family need to be revised.

\section{Keywords}

Volhynia, castle and land court books, marriage, family, husband, wife, parents, children, intra-family relations dotyczące wczesnonowożytnej rodziny ukraińskiej wymagają rewizji.

\section{Słowa kluczowe}

Wołyń, księgi sądowe grodzkie i ziemskie, małżeństwo, rodzina, mąż, żona, rodzice, dzieci, stosunki wewnątrzrodzinne

The new paradigm of social history pursues all facets of life, including the private lives of people from past epochs in their structural unity and at the intersection of social ties, cultural and historical traditions. The key focus is on a single individual, whose social status and experience are analyzed in the context of the local social community.

For every person throughout their lifetime from birth until their final days, family is the closest and most important social group. This is particularly true for early modern times, when the "household" in the sense of the "family" as the closest social community to an individual was the foundation of their entire social life. Family ties that connected blood relatives, close relatives and in-laws were a much stronger bond compared to nowadays and they were consciously and carefully fostered because the family represented the continuity of the whole lineage. Because family ties and relationships were at the core of everyday life, their restoration allows us to subsequently reconstruct the local structures (separate and extended families) and networks of personal relationships in private family life.

As discussed by Cezary Kuklo and Piotr Guzowski, Polish-based research on the family in the medieval and early-modern periods is based on a multitude of sources, such as parish registers and court books, records of head taxes, inventories of private estates, and "status animarum" church books that list the residents of Roman Catholic parishes. ${ }^{1}$ Ukrainian researchers do not have such a variety of sources to study the history of the Ukrainian family in the $16^{\text {th }}$ and $17^{\text {th }}$ centuries. At the same time, among available written sources, there exists

${ }^{1}$ Cezary Kuklo, Demografia Rzeczypospolitej przedrozbiorowej (Warszawa: Wydawnictwo DiG, 2009), 15; Cezary Kuklo, "Badania nad demografią rodzin w mieście doby przeindustrialnej”, in: Struktury demograficzne rodziny na ziemiach polskich do polowy XX wieku. Przeglad badań i problemów, eds. Piotr Guzowski, Cezary Kuklo (Białystok: Instytut Badań nad Dziedzictwem Kulturowym Europy, 2014), 52; Piotr Guzowski, "Badania demograficzne nad rodziną wiejską w okresie staropolskim", in: Struktury, 13-17; Piotr Guzowski, "Demografia rodziny szlacheckiej w świetle najnowszych badan genealogicznych", Przeszłość Demograficzna Polski 30 (2011): 9-10. 
an array of judicial and administrative books from the $15^{\text {th }}-18^{\text {th }}$ centuries, which today amount to a total of seven-and-a-half thousand volumes and contain about five million documents. ${ }^{2}$ To study the history of the Ukrainian family in early modern times, most important is the set of castle and land court records (acta castrensia et terrestria) that were accumulated through the activities and operations of castle (officia castrensia capitanealia) and land (officia terrestria) courts.

In western Ukrainian lands, these court institutions were established first in the Belz, Podillian and Ruthenian voivodeships, which from the 1340s, had been made part of the Polish Crown. The expansion of the Crown law on these lands was finalized as a result of the privilege of Jedlnia and the judicial and administrative reform of 1434-1435. ${ }^{3}$ In Ukrainian lands, in particular in Volhynia, which was a part of the Grand Duchy of Lithuania (henceforth: GDL), similar courts were established in every voivodeship county as a result of the 1564-1566 administrative and court reform. The policies and procedures of castle and land courts were stipulated in the 1566 Statute. ${ }^{4}$ Castle courts were headed by a starosta (capitaneus). Apart from him, other court officials included a vice-starosta (vicecapitaneus), a castle court judge (iudex castri), and a castle scribe (notarius castri). The starosta was appointed by the king, and other court officials by the starosta. Land courts in the contemporaneous judicial system had special status because the members of the court administration - the judge, vice-judge and the scribe - were elected from among the county szlachta and hence, formally, these courts were independent of the authorities. Castle court jurisdiction included criminal cases of assault, arson, highway robbery, violence against women, etc. Land courts mainly dealt with civil cases brought by the county's landed gentry. An important function of land courts was the so-called "eternity" right, that is, the right to notarize private transactions of real estate and property, contracts and other documents making them legally binding. However, in the course of time, the functions of the courts overlapped and the notarization of private agreements was soon also managed by castle courts.

Castle and land courts existed in Ukrainian lands for several centuries: in the west, until their abolition by the Austrian government in 1772, while in rightbank Ukraine they were brought to an end by the Russian government in the

\footnotetext{
${ }^{2}$ Oleh Kupchynskyi, "Pro pidhotovku kataloha sudovo-administratyvnykh fondiv Ukrainy XV-XVIII st.”, Arkhivy Ukrainy 5 (1976): 16.

${ }^{3}$ Stanisław Kutrzeba, "Przywilej jedlneński z 1430 r. i nadanie prawa polskiego Rusi", in: Księga pamiątkowa ku czci Bolesława Ulanowskiego (Kraków: Drukarnia Uniwersytetu Jagiellońskiego, 1911), 271-301.

4 "Statut Velykoho kniazivstva Lytovskoho 1566 roku" (henceforth: Statut 1566 r.), in: Statuty Velykoho kniazivstva Lytovskoho, eds. Serhii Kivalov, Petro Muzychenko, Anatolii Pankov, vol. 2 (Odesa: Yurydychna literatura, 2003), 90-124, 294-325.
} 
1830s. The establishment of these judicial institutions, the functioning of their chanceries and their activities received close attention in the Polish and Ukrainian literature. ${ }^{5}$ Castle and land courts functioned for over 300 years in the counties of Volodymyr, Kremenetsk and Lutsk of the Volhynian voivodeship, and their accounts were recorded in court books.

Over the centuries, the books went through a rather difficult experience. Somewhat better was the destiny of the court books of western Ukrainian lands, where fairly complete sets of the $15^{\text {th }}-17^{\text {th }}$-century books survived. At the end of the $18^{\text {th }}$ century they were deposited in the Bernardine Monastery in Lviv and consequently, this collection was labelled the Bernardine Archive. ${ }^{6}$ Its records were published over the period 1868-1935 in the 25-volume "Akta grodzkie i ziemskie z czasów Rzeczypospolitej Polskiej z archiwum tak zwanego bernardyńskiego we Lwowie". A thorough description of these books and the reconstruction of those lost were made by Przemysław Dąbkowski.?

The court books of Ukrainian lands that were first a part of the GDL and later of the Polish-Lithuanian Commonwealth sustained considerable damage: many of them perished in wars, floods, fires and other calamities. For instance, out of 583 books from the Vinnitsa court, only 14 survived. Among the Volhynian books, those from Kremenetsk castle court suffered the largest losses, with many perishing during the 1648-1654 uprising. From the documents of 1541-1542, only two remain, while the books from the years 1570, 1577-1580, 1582, 1586-1587, 1598,1603 and 1611 are lost forever. In the post-war period, Kyiv archivists restored and bound anew 138 bundles (almost 60,000 sheets) of Kremenetsk books dating from 1542-1699, which for a long time had been in a state of disintegration.

The Volhynian court books were placed in the Central Archives of Ancient Acts in Kyiv, which was created specifically for their preservation (nowadays, the Central State Historical Archives of Ukraine in Kyiv; henceforth: CDIAUK). Credit for their preservation goes to the members of the Kyiv Archeographical Commission, established in 1843. Only one-third of the collection that they assembled has survived to the present day, as it sustained significant losses during World War II: out of 6,027 books from the $16^{\text {th }}-18^{\text {th }}$ centuries, only 1,894 remain. Owing to an active post-war search by archivists, the CDIAUK currently possesses 2,119 court books from the right-bank Ukraine of the $16^{\text {th }}-18^{\text {th }}$ centuries.

\footnotetext{
${ }^{5}$ See references in: Nikolai Kovalskii, Istochnikovedenie istorii Ukrainy XVI-pervoi poloviny XVII vv., vol. 4 (Dnepropetrovsk: Dnepropetrovskii Gosudarstvennyi Universitet, 1979), 73-76.

${ }^{6}$ Iaroslav Isaevich, "Grodskie i zemskie akty - vazhneishii istochnik po istorii agrarnykh otnoshenii v Rechi Pospolitoi v XVI-XVIII vv." in: Ezhegodnik po agrarnoi istorii Vostochnoi Evropy, 1961 g. (Riga: Izdatelstvo Akademii nauk Latviiskoi SSR, 1963), 91.

${ }^{7}$ Przemysław Dąbkowski, Zaginione księgi sądowe województwa ruskiego i betskiego (Lwów: Towarzystwo Naukowe we Lwowie, 1921).
} 
796 volumes in the collection pertain to the early modern period, of which 643 are books from the Volhynian voivodeship. ${ }^{8}$

The CDIAUK court books formed the core of the multi-volume series "Arkhiv Ugo-Zapadnoi Rossii” (henceforth: AUZR), published over the period 1859-1915. However, only a relatively small number of court book documents were published, which makes them especially valuable, given the fact that a great number of the originals were lost during World War II. At the same time, a compilation of book inventories, i.e., lists of records, commenced. In the course of 1862-1909, 163 inventories were compiled, of which 80 were published and another 83 remained as manuscripts. The compilation of inventories continued in the 1920s and by 1929 , another 217 inventories had been made. However, they were never published and almost all perished during the war. ${ }^{9}$

$* * *$

Castle and land court books differ in their subject matter, which was noted and classified by Lucyan Tatomir and Oktaw Pietruski, the editors of "Akta grodzkie i ziemskie". Among castle court books, they distinguish three types - books of records (libri inscriptionum), reports (libri relationum), and powers of attorney (libri plenipotentionum); among those of land courts - books of decrees (libri decretorum), sentences (libri condemnationum), and registers of court cases (regestra causarum).$^{10}$ Based on a study of the Sanok castle court books, Janusz Łosowski designed a content-based classification of their records into judicial, property and financial, tax, political and military, that are further divided into subgroups. ${ }^{11}$ Ukrainian researchers group both the castle and land court books of Volhynia into books of decrees (libri decretorum), books of records (libri inscriptionum), and books of day-to-day matters that, according to historians and archivists, correspond to books of reports (libri relationum). ${ }^{12}$

The Volhynian castle and land court books feature a number of distinct characteristics relative to the equivalent books in Polish lands. In contrast to Galicia,

${ }^{8}$ CDIAUK, f. 21 Kremenetskyi grodskyi sud; f. 22 Kremenetskyi zemskyi sud; f. 25 Lutskyi grodskyi sud; f. 26 Lutskyi zemskyi sud; f. 27 Volodymyrskyi zemskyi sud; f. 28 Volodymyrskyi grodskyi sud.

${ }^{9}$ Kremenetskyi zemskyi sud. Opysy aktovykh knyh XVI-XVII st., ed. 1: books 1-11 (Kyiv: Centralnyi derzhavnyi istorychnyi arkhiv Ukrainskoi RSR, 1959), 4-5, 209-222.

${ }^{10}$ Akta grodzkie i ziemskie z czasów Rzeczypospolitej Polskiej z archiwum tak zwanego bernardyńskiego we Lwowie, vol. 1 (Lwów: Zakład Narodowy im. Ossolińskich, 1868), 7.

${ }^{11}$ Janusz Łosowski, Kancelaria grodzka chetmska od XV do XVIII wieku: studium o urzędzie, dokumentacji, jej formach $i$ roli $w$ zyciu społeczeństwa staropolskiego (Lublin: Wydawnictwo UMCS, 2004), 165-180.

${ }^{12}$ Isaevich, "Grodskie i zemskie akty”, 92. 
where, in the $16^{\text {th }}$ and $17^{\text {th }}$ centuries, court books (except for those of rural communities) were written mainly in Latin, in $16^{\text {th }}$ century Volhynia, court books were written in Ukrainian with minor elements of Polish and Latin terminology. In the $17^{\text {th }}$ century, some records were written in Polish. Certainly, back in those times, scribes adhered to contemporary models of record-keeping, using expressions and terminology typical of officialese. However, through the official language, elements of spoken vocabulary made their way into a framework of standard, formal and business-like stating of facts, which was documented in testimonies of court officers (woźny), inventories of personal belongings, speeches of case participants, testimonies of witnesses, etc.

Documents were recorded into books in the order in which they were received. If there were few, a year book was assembled; if there were many, they were divided into several volumes by months. The number of sheets in the books varies, and sometimes exceeds two thousand. There was no system for grouping records by subject matter or specific issues.

An important feature of the castle and land courts was that, in addition to judicial functions, they also carried out functions of notary institutions, i.e., they notarized documents of private property rights. The following documents were filed there: real estate purchase and sale agreements (venditio, emptio, resignatio), division of estates among heirs (ad attentandam exdivisionum), investiture with estate ownership (intromissio), cession records (cessio), pledge records ( $o b$ ligatio), exchange agreements (commutatio), dowry allocations to daughters (dos, reformatio dotis), renunciation of estate ownership rights upon receiving dowry (abrenuntiatio), marriage contracts (intercisa), dowry insurance records (dotalitium), gift deeds (donation), lifetime maintenance provisions (advitalitas), testaments (testamentum), complaints (protestaciones, manifestationes), guardianship records (inscriptio tutelage), various quittances (quietatio), proof of noble origins (deductio nobilitatis), etc. Most agreements and records were of a financial or business nature and were settled within a family or amongst relatives. Consequently, a significant number of court records contain explicit information on lineal and collateral consanguinity, marriage ties, and relationships between blood and close relatives. ${ }^{13}$ It would be sufficient to give the following example: Lutsk book number 3 of $1560-1561$, which is one of the smallest, contains 383 documents, of which 256 directly concern various aspects of family life. ${ }^{14}$ Overall, 643 Volhynian court books contain hundreds of thousands of such records.

${ }^{13}$ Iryna Voronchuk, Naselennia Volyni $v$ XVI-pershii polovyni XVII st.: rodyna, domohospodarstvo, demohrafichni chynnyky (Kyiv: Feniks, 2012), 40-61.

${ }^{14}$ CDIAUK, f. 25 , op. 1 , spr. 3. 
By sheer volume and content, they represent an important comprehensive source for studying the history of the early-modern Ukrainian family.

Below, we discuss the most important records that help reconstruct family structures. The core of any family is the married couple; hence, in order to reconstruct a family we first need to establish a married couple. The data on spouses are contained in numerous documents of private law: marriage contracts, dowry insurance records, gift deeds, quittances, property documents, testaments, etc. The betrothal of minors was a widespread practice not only in ducal but also in the ordinary szlachta milieu. Marriage contracts were governed by economic considerations and the social ambitions of parents. It should be noted that marriage contracts require additional verification because preliminary agreements did not always result in marriages. Such was the case of Janusz Uhrynowski. When he was still a boy, his father made an agreement to marry him to Illiasz Nieswiecki's daughter. However, Illiasz later changed his mind, and on the wedding day refused to give Janusz his daughter's hand..$^{15}$ In another case, Lazar Iwanicki sued Josyf Niemirycz for violating the agreement to give his daughter Nastasia in marriage to him. ${ }^{16}$ On September 23, 1576, Żdan Bronnicki, his daughter Maria and their guests waited in vain for the wedding ceremony because Pawel Uhlyk Sokolynski, who a year earlier had asked her hand in marriage, never appeared. ${ }^{17}$

In terms of credibility, dowry insurance records are particularly trustworthy sources as they testify to the fact that a marriage took place. Dowry insurance records represent a significant fraction of book records owing to the guideline of the First Lithuanian Statute of 1529 that, prior to giving their daughter into marriage, parents should receive a dowry insurance record from their future sonin-law so that she would not lose the dowry she would bring into her husband's household..$^{18}$ This regulation was elaborated on in the fifth chapter of the Second Statute (1566), which also required a husband to officially register a dowry insurance record for his wife and secure it on his immovable property. Because a woman would lose her dowry without a dowry insurance record, parents and relatives of a bride made sure that the statute was observed. ${ }^{19}$

\footnotetext{
${ }^{15}$ Ibidem, f. 25, op. 1, spr. 5, ark. 170-172zv.

${ }^{16}$ Ibidem, f. 28, op. 1, spr. 1, ark. 85-87.

${ }^{17}$ Ibidem, f. 25, op. 1, spr. 16, ark. 414-416.

18 "Statut Velykoho kniazivstva Lytovskoho 1529 roku" (henceforth: Statut 1529 r.), in: Statuty, vol. 1, 89, 230.

${ }^{19}$ Statut 1566 r., 125.
} 
Due to this practice, court books that registered dowry insurance records contain information on a husband and wife: their names, surnames and patronymics. For example, from the dowry insurance record of Iwan Czaplic Szpanowski in favour of his wife Raina from Chodorowy Staw of December 9, 1574, we learn that they were indeed a married couple. ${ }^{20}$ Sometimes dowry insurance records contain extended information, especially on the bride's family, because when a husband registered a dowry insurance for his wife, he named the person from whom he had received the dowry. For instance, the dowry insurance record of September 21, 1578, by Teodor Zloba Czernski on behalf of his wife Maryna Hulewiczówna contains information on her mother Polagna Ozdowska, her three brothers, Zloba's first wife Magdalena Olyczanka and the children he had with her. Further, because Zloba Czernski took Maryna's dowry from the hands of her brothers, it is evident that her father Roman Hulewicz was no longer alive. ${ }^{21}$ Thus, dowry insurance records allow us to establish couples who married four to five hundred years ago.

Deeds of gifts of movable and immovable property by spouses also help us identify married couples. Typically, gift deeds were bilateral: if one of the spouses gave a "gift" to the other, then the other often simultaneously registered a "give back" deed. deed. In the gift deed registered on July 17, 1561, by Tatiana Przyweredowska in favour of her husband Iwan Kałusowski, she mentioned her first husband Hniwosz Hurka and her blood brothers, Michał and Wasyl. ${ }^{22}$ Hence, we learn that Tatiana had married for the second time and we also learn the names of her two husbands and gain partial information about her parental family.

Family information is also contained in a variety of property documents such as purchases and sales, exchanges of estates, mortgages, leases, etc. For instance, on December 29, 1563, Anna Żabokrycka borrowed a sum of money from her nephew Roman Krasnoselski using as a collateral her part of Żabokryky village, which she had inherited together with her five sisters following the death of their brother, Wasyl. The record lists her sisters under their husbands' names and surnames. ${ }^{23}$ Thus, we obtain complete data on the entire generation of the Żabokrycki family.

Among the different types of records, testaments contain the most comprehensive information on families because not only do they reveal actual married couples, but sometimes they also mention previous marriages. Most importantly, they include information on children, which is essential for understanding

\footnotetext{
${ }^{20}$ CDIAUK, f. 25 , op. 1 , spr. 15 , ark. 56-57.

${ }^{21}$ Ibidem, f. 25, op. 1, spr. 18, ark. 673zv.

${ }^{22}$ Ibidem, f. 25, op. 1, spr. 3, ark. 161-162.

${ }^{23}$ Ibidem, f. 25, op. 1, spr. 5, ark. 234-235zv.
} 
demographic behavior and for establishing family compositions, structures and typologies. An example is the testament of Mihał Liniewski, dated May 15, 1597, in which he named his eight adult children born from two marriages to Lubka Szelwowska and Raina Czerniewska. He also mentioned his young children, but without naming or counting them. ${ }^{24}$ Sometimes testaments mention the names of close and blood relatives of lineal and collateral consanguinity. However, testaments are rare and not all of them are exhaustive; for example, sometimes they mention children but not their number or gender.

Court records on the division of estates among relatives (ad attentandam exdivisionum) and protests (protestationes) against unfair property distribution or its illicit appropriation are the most valuable in establishing extended family (kin) relations. Usually in such cases, a wide circle of interested parties would be involved, and, in order to confirm the legality of their inheritance rights, they would present antecedent documents: grand-ducal and royal letters, charters, privileges, deeds of gift, deeds of purchase, etc., featuring their ancestors' names, especially male ones. For example, from the court book record of June 30, 1585, on the division of real estate amongst the heirs of the late Matiasz Ostryjewski, we obtain information on nine separate families, with four married couples, and can establish the relationships among them. ${ }^{25}$ Similar information is contained in complaints of relatives against each other about misappropriation of property. For instance, in 1585, Tychon Rzyszczowski, in his name and on behalf of his sister and close relatives, the spouses Andrzej Kuzmiński and Ogrefina Czarukowska, filed a lawsuit against Mark Zbranny, accusing him of taking advantage of their young age and seizing their matrilineal inheritance, the estate of Kniahinin. In an attempt to prove the legitimacy of his rights, Tychon submitted three documents to the court: two letters of 1554 and a claim of 1560, from which it follows that Tychon Rzyszczowski and Mark Zbranny had common grandparents and their mothers were sisters. Zofia Czarukowska, Zofia Ozdowska, Semen and Teodor Bajewski also claimed their rights to Kniahinin. ${ }^{26}$ Based on this case, we have obtained information on six married couples, nine families and their kinship ties.

Overall, the numerous court records provide valuable and necessary information for the reconstruction of families because, in addition to naming the parties to judicial proceedings, they also specify their family relationships and ties. Thus, applying the genealogical method to these data, it is possible to reconstruct the family structures of szlachta in the early modern period.

\footnotetext{
${ }^{24}$ Ibidem, f. 26, op. 1, spr. 11, ark. 115-117zv.

${ }^{25}$ Ibidem, f. 26, op. 1, spr. 5, ark. 292zv. -307.

${ }^{26}$ Ibidem, f. 26, op. 1, spr. 5, ark. 340zv.-342zv.
} 
A number of scholars, starting with Ignacy Kapica Milewski, have demonstrated the importance of court books for genealogical research ${ }^{27}$ Therefore, it may seem that researching court books is not topical, and yet in Ukrainian historiography they are a rather novel source because despite their well-understood importance, court books have remained largely overlooked by Ukrainian historians.

The foundations of Ukrainian genealogy were laid by Polish scholars, in particular, Bartosz Paprocki, Szymon Okolski, Kasper Niesiecki, Benedykt Chmielowski, Wojciech Wielądko, Stanisław Kazimierz Kossakowski, Adam Am. Kosiński, Jerzy Dunin-Borkowski, Teodor Żychlinski, Adam Boniecki, Seweryn Uruski, Juzef Wollf, Wiktor Wittyg, Kazimierz Pułaski and Juzef Puzyna. ${ }^{28}$ They constructed family trees not only of Polish but also of Ukrainian szlachta, who were a part of the Commonwealth elite of the time. These scholars relied on various sources but they had no or limited access to the documentary material in the Ukrainian archives. The first to draw on the Volhynian court books was A. Boniecki, who used book inventories that had been published. Our experience with book inventories has shown their limitation: they do not fully reveal family relations and intra-family ties, the information on which is contained in the records themselves. Kazimierz Pułaski used some of the records published in the AUZR. He wrote 22 essays on the Volhynian szlachta and traced the lineages of nine families, the Borejkowie, Hosccy, Illińscy, Olizarowie, Niemiriczowie, Owłoczyńscy, Piaseczyńscy, Szaszkiewiczowie, and Woroniczowie, from the $15^{\text {th }}$ and $16^{\text {th }}$ centuries. $^{29}$

Although the castle and land court books mostly involve ordinary szlachta, they also help broaden our knowledge of some of the famous ducal families. For example, the Volhynian books of the $16^{\text {th }}$ and mid-1 $17^{\text {th }}$ centuries allowed us to augment the family tree of the Ruzhinski dukes by 26 previously unknown members. ${ }^{30}$ We have also discovered information on the genealogies of the Puzyn, Massalscy, Woronieccy dukes and others.

${ }^{27}$ Ignacy Kapica Milewski, Herbarz Ignacego Kapicy Milewskiego: dopetnienie Niesieckiego (Kraków: Druk “Czasu” W. Kirchmayera, 1870).

${ }^{28}$ Włodzimierz Dworzaczek, Genealogia (Warszawa: PWN, 1959), 109-121; Iryna Voronchuk, Rodovody volynskoi shliakhty XVI - pershoi polovyny XVII st. (rekonstruktsiia rodynnykh struktur: metodolohiia, metodyka, dzherela) (Kyiv: Vyshcha shkola, 2009), 104-120.

${ }^{29}$ Kazimierz Pułaski, Kronika polskich rodów szlacheckich Podola, Wotynia i Ukrainy, t. 2 (Warszawa: Wydawnictwo DiG, 2004), 29-34, 73-80, 80-89, 136-149, 156-164, 164-165, 167194, 239-245, 263-285.

${ }^{30}$ Voronchuk, Rodovody, 120-136. 
Research on the history of the Ukrainian family emerged in the late $19^{\text {th }}$ century when the works of Orest Levitskii were published. Focusing on everyday family life in the $16^{\text {th }}$ and $17^{\text {th }}$ centuries, Levitskii concluded that in Ukrainian society, women were almost equal to men in exercising their civil rights. ${ }^{31}$ Based on the materials published by O. Levitskii, Aleksander Jabłonowki and Juliusz Bardach explored family relationships in $16^{\text {th }}$ - and $17^{\text {th }}$-century Volhynia. A. Jabłonowki argued that to a great extent, family relations were governed by customs, provisions of Byzantine canon law, the Lithuanian Statutes, and the implications of both Unions. In his opinion, Ukrainian magnates, when becoming relatives in Polish families, assumed Polish models of family household life, while lesser szlachta continued to follow old customs. ${ }^{32} \mathrm{~J}$. Bardach studied the existing practices of marriage agreements and the freedom of divorce. ${ }^{33}$ Izydor Szaraniewicz and Kazimierz Sochaniewicz wrote on the subject of divorce, using documents from western Ukrainian lands. ${ }^{34}$

Thereafter, research on the history of the Ukrainian family by Ukrainian historians was interrupted, and hence a whole spectrum of topics in the history of the early modern Ukrainian family have hardly been touched upon. However, as one of the founders of the anthropological approach to history Marc Bloch said, without looking into people's private lives, history becomes a kind of dead history, a history without individuals, while its main subject are people..$^{35}$

To establish the characteristics of the early modern Ukrainian family, we used the court records to construct the family trees of ordinary Volhynian szlachta. That allowed us to estimate various demographic statistics, such as the average

${ }^{31}$ Orest Levitskii, "Cherty semeinogo byta v Ugo-Zapadnoi Rusi v XVI-XVII vv.”, in: Arkhiv Ugo-Zapadnoi Rossii, izdavaemyi vremennoi komissiei dlia razbora drevnikh aktov sostoiashchei pri Kievskom, Podolskom i Volynskom general-gubernatore, part 8, vol. 3: Akty o brachnom prave i semeinom byte $v$ Ugo-Zapadnoi Rusi v XVI-XVII vv., (Kyiv: Tipografiia Imperatorskogo universiteta sv. Vladimira, 1909), 6-7.

${ }^{32}$ Aleksander Jabłonowski, "Stosunki rodzinne na Wołyniu na przełomie XVI-go i XVII-go wieku", Przeglad Historyczny 12 (1911), 2: 210-215; 13 (1911), 1: 57-66; 13 (1911), 2: 203-214; 13 (1911), 3: 347-361.

${ }^{33}$ Juliusz Bardach, "Świecki charakter zwyczajowego prawa małżeńskiego ludności ruskiej Wielkiego Księstwa Litewskiego (XV-XVII wiek)", Czasopismo Prawno-Historyczne 15 (1963), 1: $85-148$.

${ }^{34}$ Kazimierz Sochaniewicz, "Rozwody na Rusi Halickiej w XV i XVI wieku", Pamiętnik Historyczno-Prawny 7 (1929), 3: 29; Izydor Szaraniewicz, Rys wewnętrznych stosunków Galicyi wschodniej $w$ drugiej połowie XV wieku (Lwów: W drukarni Instytutu Stauropigijskiego, 1869), 30.

${ }^{35}$ Marc Bloch, Apologie pour l'histoire ou Métier d'historien (Paris : Librairie Armand Colin, 1952), 17. 
birth rate and the number of children, and to characterize marriage and it is determinants, and the structure and features of family organization.

The results reveal that the model of the early modern Ukrainian family differs from the contemporaneous Polish equivalent. Contrary to the conclusions of Polish historians and demographers on the custom of late marriages in Polish society, the documents in the Volhynian court books evidence that early age marriages prevailed in Ukrainian lands.

According to the Statutes of 1529 and 1566, women were considered adults at the age of 15 but the Statute of 1588 changed that - the age of adulthood for men remained the same, but for girls it was lowered to the age of $13 .{ }^{36}$ The shift in the law suggests that in practice, the 15-year age norm was not observed and girls were often married earlier. It is generally acknowledged that legislation tends to lag behind reality; hence, the norm was modified to suit the existing practices of the time. Moreover, according to canon law, girls at the age of 12 and boys of 14 had the right to marry. ${ }^{37}$ We agree with Piotr Guzowski, who points out that it is likely that at the age of 12 , girls were not yet married. However, as O. Levitskii argues, at the end of the $16^{\text {th }}$ century, the old Ruthenian custom of child betrothal was practiced in Volhynia. ${ }^{38}$ Relying on Polish sources, Maria Koczerska also documents the tradition of the early marriages of women. ${ }^{39}$ Castle and land court records suggest that the age of 14 was considered acceptable for girls to be married off and, as confirmed by testaments, their marriages were promptly arranged..$^{40}$ Occasionally, the age of married women is provided or implicitly suggested. For example, Anna Montowtówna at the age of 17 was married for the second time. ${ }^{41}$ Anna Ostykówna at the age of 16 was the wife of Duke Lew Sanguszko Koszerski, Helena Dobryńska at age of 15 was the wife of Adrzej Bram, and Bohdana Siemaszkówna fell pregnant at the age of $15 .{ }^{42}$ Owdotja Szpakowska stated that she was married off "before coming of age", that is, before she was $13 .^{43}$ Sometimes sons were married at an early age too. In 1564, Duke Stefan

${ }^{36}$ Statut 1529 r., 58; Statut 1566 r., 133; "Statut Velykoho kniazivstva Lytovskoho 1588 roku", in: Statuty, vol. 3, book 1, 525.

${ }^{37}$ Inokentii Gizel, Myr z Bohom choloviku. Vybrani tvory u 3-kh tomakh, vol. 1, book 1 (KyivLviv: Svichado, 2012), 166.

${ }^{38}$ Guzowski, "Demografia”, 20; Levitskii, "Cherty", 17-19.

${ }^{39}$ Maria Koczerska, Rodzina szlachecka w Polsce późnego średniowiecza (Warszawa: PWN, 1975), 30-32.

${ }^{40}$ CDIAUK, f. 26 , op. 1 , spr. 5, ark. 41; f. 25, op. 1, spr. 15, ark. 158-159.

${ }^{41}$ AUZR, part 8, vol. 3, 80-81.

${ }^{42}$ Juzef Wolff, Kniaziowie litewsko-ruscy od końca czternastego wieku (Warszawa: Drukiem J. Filipowicza, 1895), 204-205; CDIAUK, f. 26, op. 1, spr. 4, ark. 531zv.-532zv.; f. 25, op. 1, spr. 12 , ark. $372-374$.

${ }^{43}$ CDIAUK, f. 26, op. 1, spr. 7, ark. 171-172zv. 
Zbaraski contracted an agreement to marry off his 16-year old son Piotr and the marriage took place the very same year. ${ }^{44}$

The difference between the early-age marriage norm amongst ordinary Ukrainian szlachta and the late-age marriage tradition of their Polish counterparts manifested itself in differences in their demographic behaviour. Family trees constructed on the basis of the court books testify to relatively high birth rates among ordinary Volhynian szlachta and even in ducal families. ${ }^{45}$ For example, it was previously thought that eight children were born into the ducal marriage of Aleksander Zasławski and Eufrozyna Ostrogska, yet more recent research shows they had at least 11 children. ${ }^{46}$ Dowry insurance records allow us to conclude that having many children was approved by the prevailing societal mentality. The custom of early marriages and a relatively large number of offspring is supported by the fact that, despite a high mortality rate and loss of lives due to frequent incursions by Crimean Tatars, the early modern Volhynian population was steadily increasing. ${ }^{47}$ Early-age marriages were also practised in western Ukrainian lands, which is supported by the estimates of the average size of the szlachta family in the Przemyśl land in the $15^{\text {th }}$ and $16^{\text {th }}$ centuries. ${ }^{48}$

It should be noted that a general register of early modern szlachta families from higher to lower strata has not yet been compiled by Ukrainian historians. The "Polska encyklopedia szlachecka" contains 623 surnames of Volhynian szlachta. ${ }^{49}$ As of today, the author's archive comprises more than 400 unknown Volhynian families, the surnames of whom were found in the Volhynian court books.

$* * *$

Court books also allow us to revise stereotypical views of the position of women in the Ukrainian family of the period. In particular, Orest Levitskii argues that the Ukrainian woman enjoyed freedoms, including the right to choose her husband freely. In making the argument, O. Levitskii refers to the clauses of the Lithuanian Statutes that prohibited forced marriages of girls/widows and required that they were provided with economic security, which, in his opinion, was the

\footnotetext{
${ }^{44}$ Wolff, Kniaziowie, 613-615.

${ }^{45}$ Voronchuk, Rodovody, 179-307.

${ }^{46}$ Voronchuk, Naselennia, 111.

${ }^{47}$ Ibidem, 454-456.

${ }^{48}$ Ihor Smutok, Ruska shliakhta Peremyshlskoi zemli (XIV-XVIII st.). Istoryko-henealohichne doslidzhennia (Lviv: Prostir-M, 2017), 101-105.

${ }^{49}$ Polska encyklopedia szlachecka, vol. 4-12 (Warszawa: Wydawnictwo Instytutu Kultury Historycznej, 1935-1938).
} 
key economic reason for women's independence. ${ }^{50}$ It is, however, hard to agree with his view because other clauses entirely excluded women's right to exercise their free will when choosing marriage partners, under the threat of losing dowries or matrilineal inheritance. Furthermore, the Statutes also stipulated that the marriage decisions of orphan girls were under the control of their closest relatives - their brothers and uncles. ${ }^{51}$

To have a better understanding of contemporary realities, let us compare the legislative provisions with the existing practices that were recorded in court books. Arguing that women could exercise free will in choosing their husbands, O. Levitskii cites the statement of the Volhynian noble woman Anna Montowtówna who, in 1564, in the presence of her father, testified that her decision to marry Duke Vasyl Sokolsky was her own. Thus, O. Levitskii concludes that in the second half of the $16^{\text {th }}$ century, the free-will norm had found its way not only into societal consciousness but also into social practice. However, O. Levitskii overlooks the statement of her father, Jan Montowt, who declared that he had personally arranged her marriage to Duke Sokolski. ${ }^{52}$ We have uncovered three documents clarifying this case. The first one is the complaint of Anna Montowtówna against a friend of her deceased first husband, Josyf Niemirycz, who tried to force her into marriage to his relative Iwan Olizarowicz. ${ }^{53}$ The other two shed even more light on marriage practices - it is the complaint of Iwan Olizarowicz against Duke Wasyl Sokolski who had taken away his alleged wife Anna Montowtówna, and the truce agreement between the two, according to which Iwan Olizarowicz ceded "his rights" to marry Anna to the Duke for 1,200 kops (3,000 złotych). ${ }^{54}$ Hence, when declaring the expression of "free will" by his daughter, Jan Montowt was trying to protect himself from the likely claims of Niemirycz.

Marriage contracts and various complaints show that not only girls and widows but also sons had to obtain the permission of their parents or relatives to marry. ${ }^{55}$ The decisive role of parents and/or guardians in choosing a marriage partner is explained not only by customs. Economic and financial levers were on the side of parents because it was they who provided their sons with real estate that secured the future wife's dowry. However, parents were in no hurry to endow their sons with real estate and often a dowry insurance record to the wife's benefit was made not by the husband but by his father. For instance, in 1584, when Kindyn

\footnotetext{
${ }^{50}$ Levitskii, "Cherty", 6.

${ }^{51}$ Statut 1529 r., 89-90, 91, 231; Statut 1566 r., 128-129, 330-331.

${ }^{52}$ CDIAUK, f. 25, op. 1, spr. 6, ark. 228.

${ }^{53}$ Ibidem, f. 25, op. 1, spr. 6, ark. 228zv. -229.

${ }^{54}$ Ibidem, f. 25, op. 1, spr. 6, ark. 261.

${ }^{55}$ Ibidem, f. 25 , op. 1 , spr. 12 , ark. $462-467$; spr. 6, ark. 221-222; spr. 12, ark. 462-467; ark. 583-583zv.; spr. 13, ark. 581-581zv.; 626zv.-627zv.
} 
Chomiak Smordowski was marrying for the second time, it was his father Tychon who made a dowry insurance record for his future daughter-in-law because he had not yet granted his son any real estate. ${ }^{56}$

Marriage was of a totally pragmatic nature. A wide circle of relatives participated in selecting a marriage partner as it affected the financial and social interests of the entire kinship network. Zbigniew Kuchowicz believes that in marriages amongst szlachta, love and feelings played an even smaller role than they did amongst lower classes. ${ }^{57}$

Our research calls for a revision of the prevailing notion of ideal marital and, more generally, family relationships that was drawn from dowry insurance records ${ }^{58}$ It is generally believed that the woman, although deprived of participation in public life, held a dignified position in szlachta society. ${ }^{59}$ However, a thorough analysis of court books does not confirm this idyllic impression. As a rule, in response to dowry insurance records, deeds of gift or lifetime maintenance provisions made by their husbands, women in return instantaneously registered "give back" deeds to the benefit of their husbands. For example, upon marrying Eustachy Malinski, Aleksandra Odyncówna passed on all her real estate rights forever to her husband. ${ }^{60}$ Motrona Iwanicka vested her husband with unlimited rights to manage her real estate. ${ }^{61}$ In response to Prokop Szelwowski's deed of gift, the very same day, his wife Magdalena Kraseńska renounced her estate rights to his benefit. ${ }^{62}$ The list of similar cases goes on and on.$^{63}$ It should be pointed out that women were often coerced by their husbands into registering deeds of gift to their benefit. Also, men often did not adhere to the law and did not register dowry insurance records to the benefit of their wives or, having registered their estates as collateral for their wives' dowries, men continued to manage them at their own discretion. ${ }^{64}$

A significant number of records illustrate the relationships between parents and children. There are numerous examples of friendly family coexistence; however, by their very nature, many court records document difficulties in family

${ }^{56}$ Ibidem, f. 26, op. 1, spr. 4, ark. 487-490zv.

${ }^{57}$ Zbigniew Kuchowicz, Obyczaje i postacie Polski szlacheckiej XVI-XVIII wieku (Kraków: Polonia, 1993), 44.

${ }^{58}$ Levitskii, "Cherty", 64.

${ }^{59}$ Kuchowicz, Obyczaje, 49.

${ }^{60}$ CDIAUK, f. 26, op. 1, spr. 13, ark. 123-125zv.

${ }^{61}$ Volynski gramoty XVI st. (Kyiv: Naukova dumka, 1995), 50.

${ }^{62}$ CDIAUK, f. 26, op. 1, spr. 3, ark. 811-814zv.

${ }^{63}$ Ibidem, f. 25 , op. 1, spr. 7, ark. 161zv.-162; f. 27, op. 1, spr. 1, ark. 211zv.-212zv.; spr. 3, ark. 124-125zv.; Volynski gramoty, 85-86, 87-89.

${ }^{64}$ Ibidem, f. 25 , op. 1, spr. 5, ark. 77-78; f. 28, op. 1, spr. 2, ark. 122-123; f. 26, op. 1, spr. 13, ark. 560-570zv; f. 26, op. 1, spr. 9, ark. 330zv.-331zv.; f. 26, op. 1, spr. 11, ark. 111-112zv. 
relationships. Overall, emotional relationships were diverse and complex: from mutual understanding, love and respect to manifestations of disrespect, brutality and cruelty of men towards women, children and elders. ${ }^{65}$ While Polish historiography has been engaged in active ongoing research on family relationships, in Ukrainian historiography, such research has only just started. ${ }^{66}$ The analysis of contemporary Polish-Ukrainian marriage ties, the information on which is also contained in the $16^{\text {th }}$ and $17^{\text {th }}$ century court records, might appeal to both Polish and Ukrainian historians.

\section{$* * *$}

In conclusion, Volhynian castle and land court books are an important and relevant source for studying the history of the Ukrainian szlachta family. They provide a significant amount of data and information that help reconstruct family structures, establish kin relations, and characterize family interactions. Court books are an invaluable source as they contain extensive, comprehensive and numerous records on szlachta from its highest ranks to its lowest. This allows us to understand similarities and identify differences in the marriages and family characteristics of the wealthy and poor strata of szlachta. Documents from castle and land court books shed light not only on the degree of kinship, filiation and family ties but also on intra- and inter-family relationships, the system of values, mentality and demographic behaviour of people in that period. The history of the early modern Ukrainian family that can be reconstructed via a thorough analysis of court books allows us to see a person in a family circle, learn about norms of conduct, intra-family relations, human emotions and feelings.

\section{Bibliography}

\section{Primary Sources}

Akta grodzkie i ziemskie z czasów Rzeczypospolitej Polskiej z archiwum tak zwanego bernardyńskiego we Lwowie (1868-1935). Vol. 1-25. Lwów: Zakład Narodowy im. Ossolińskich.

Arkhiv Ugo-Zapadnoi Rossii, izdavaemyi vremennoi komissiei dlia razbora drevnikh aktov sostoiashchei pri Kievskom, Podolskom i Volynskom general-gubernatore

${ }^{65}$ Iryna Voronchuk, "Ukrainska shliakhetska rodyna rannomodernoi doby u vnutrishnikh zviazkakh i stosunkakh: batky i dity", Ukraina Lithuanica: studii z istorii Velykoho kniazivstva Lytovskoho 4 (2017), 189-205.

${ }^{66}$ Przemysław Dąbkowski, Prawo prywatne polskie, vol. 1-2 (Lwów: Towarzystwo dla Popierania Nauki Polskiej, 1910-1911); Jacek Pielas, Podziaty majątkowe szlachty koronnej w XVII wieku (Kielce: Wydawnictwo Uniwersytetu Jana Kochanowskiego w Kielcach, 2013). 
(AUZR). Part 8, vol. 3: Akty o brachnom prave i semeinom byte v Ugo-Zapadnoi Rusi v XVI-XVII vv. Kyiv: Tipografiia Imperatorskogo universiteta sv. Vladimira, 1909.

Centralnyi derzhavnyi istorychnyi arkhiv Ukrainy, m. Kyiv (CDIAUK). Fond 21: Kremenetskyi grodskyi sud; fond 22: Kremenetskyi zemskyi sud; fond 25: Lutskyi grodskyi sud; fond 26: Lutskyi zemskyi sud; fond 27: Volodymyrskyi zemskyi sud; fond 28: Volodymyrskyi grodskyi sud.

\section{Secondary Sources}

Kivalov Serhii, Petro Muzychenko, Anatolii Pankov, eds. Statuty Velykoho kniazivstva Lytovskoho. Vol 1. Odesa: Yurydychna literatura, 2002.

Kivalov Serhii, Petro Muzychenko, Anatolii Pankov, eds. Statuty Velykoho kniazivstva Lytovskoho. Vol 2. Odesa: Yurydychna literatura, 2003.

Kivalov Serhii, Petro Muzychenko, Anatolii Pankov, eds. Statuty Velykoho kniazivstva Lytovskoho. Vol. 3, book 1. Odesa: Yurydychna literatura, 2004.

Kremenetskyi zemskyi sud. Opysy aktovykh knyh XVI-XVII st. Ed. 1: books 1-11. Kyiv: Centralnyi derzhavnyi istorychnyi arkhiv Ukrainskoi RSR, 1959.

Volynski gramoty XVI st. Kyiv: Naukova dumka, 1995.

\section{References}

Bardach, Juliusz. "Świecki charakter zwyczajowego prawa małżeńskiego ludności ruskiej Wielkiego Księstwa Litewskiego (XV-XVII wiek)", Czasopismo Prawno-Historyczne 15 (1963), 1: 85-150.

Bloch, Marc. Apologie pour l'histoire ou Métier d'historien. Paris: Librairie Armand Colin, 1952.

Dąbkowski, Przemysław. Prawo prywatne polskie. Vol. 1-2. Lwów: Towarzystwo dla Popierania Nauki Polskiej, 1910-1911.

Dąbkowski, Przemysław. Zaginione księgi sądowe województwa ruskiego i betskiego. Lwów: Towarzystwo Naukowe we Lwowie, 1921.

Dworzaczek, Wlodzimierz. Genealogia. Warszawa: PWN, 1959.

Gizel, Inokentii. Myr z Bohom choloviku. Vybrani tvory u 3-kh tomakh. Vol. 1, book 1. Kyiv-Lviv: Svichado, 2012.

Guzowski, Piotr. "Badania demograficzne nad rodziną wiejską w okresie staropolskim". In: Struktury demograficzne rodziny na ziemiach polskich do połowy XX wieku. Przegląd badań i problemów, eds. Piotr Guzowski, Cezary Kuklo, 11-31. Białystok: Instytut Badań nad Dziedzictwem Kulturowym Europy, 2014.

Guzowski, Piotr. "Demografia rodziny szlacheckiej w świetle najnowszych badań genealogicznych”. Przeszłość Demograficzna Polski 30 (2011): 7-23.

Isaevich, Iaroslav. "Grodskie i zemskie akty - vazhneishii istochnik po istorii agrarnykh otnoshenii v Rechi Pospolitoi v XVI-XVIII vv.”. In: Ezhegodnik po agrarnoi istorii Vostochnoi Evropy, 1961 g., 90-99. Riga: Izdatelstvo Akademii nauk Latviiskoi SSR, 1963. 
Jabłonowski, Aleksander. "Stosunki rodzinne na Wołyniu na przełomie XVI-go i XVII-go wieku", Przeglad Historyczny 12 (1911), 2: 210-215; 13 (1911), 1: 57-66; 13 (1911), 2: 203-214; 13 (1911), 3: 347-361.

Kapica Milewski, Ignacy. Herbarz Ignacego Kapicy Milewskiego: dopetnienie Niesieckiego. Kraków: Druk "Czasu” W. Kirchmayera, 1870.

Koczerska, Maria. Rodzina szlachecka w Polsce późnego średniowiecza. Warszawa: PWN, 1975.

Kovalskii, Nikolai. Istochnikovedenie istorii Ukrainy XVI-pervoi poloviny XVII vv. Vol. 4. Dnepropetrovsk: Dnepropetrovskii Gosudarstvennyi Universitet, 1979.

Kuchowicz, Zbigniew. Obyczaje i postacie Polski szlacheckiej XVI-XVII wieku. Kraków: Polonia, 1993.

Kuklo, Cezary. "Badania nad demografią rodzin w mieście doby przedindustrialnej”. In: Struktury demograficzne rodziny na ziemiach polskich do połowy XX wieku. Przegląd badań i problemów, eds. Piotr Guzowski, Cezary Kuklo, 51-78. Białystok: Instytut Badań nad Dziedzictwem Kulturowym Europy, 2014.

Kuklo, Cezary. Demografia Rzeczypospolitej przedrozbiorowej. Warszawa: Wydawnictwo DiG, 2009.

Kupchynskyi, Oleh. "Pro pidhotovku kataloha sudovo-administratyvnykh fondiv Ukrainy XV-XVIII st.”. Arkhivy Ukrainy 5 (1976): 14-21.

Kutrzeba, Stanisław. "Przywilej jedlneński z 1430 r. i nadanie prawa polskiego Rusi". In: Księga pamiątkowa ku czci Bolesława Ulanowskiego, 271-301. Kraków: Drukarnia Uniwersytetu Jagiellońskiego, 1911.

Levitskii, Orest. "Cherty semeinogo byta v Ugo-Zapadnoi Rusi v XVI-XVII vv.". In: Arkhiv Ugo-Zapadnoi Rossii, izdavaemyi vremennoi komissiei dlia razbora drevnikh aktov sostoiashchei pri Kievskom, Podolskom i Volynskom general-gubernatore. Part 8, vol. 3: Akty o brachnom prave i semeinom byte v Ugo-Zapadnoi Rusi $v$ XVI-XVII vv., 1-120. Kyiv: Tipografiia Imperatorskogo universiteta sv. Vladimira, 1909.

Łosowski, Janusz. Kancelaria grodzka chetmska od XV do XVIII wieku: studium o urzędzie, dokumentacji, jej formach $i$ roli $w$ życiu społeczeństwa staropolskiego. Lublin: Wydawnictwo UMCS, 2004.

Pielas, Jacek. Podziały majątkowe szlachty koronnej w XVII wieku. Kielce: Wydawnictwo Uniwersytetu Jana Kochanowskiego w Kielcach, 2013.

Polska encyklopedia szlachecka. Vol. 4-12. Warszawa: Wydawnictwo Instytutu Kultury Historycznej, 1935-1938.

Pułaski, Kazimierz. Kronika polskich rodów szlacheckich Podola, Wotynia i Ukrainy. Warszawa: Wydawnictwo DiG, 2004.

Smutok, Ihor. Ruska shliakhta Peremyshlskoi zemli (XIV-XVIII st.). Istoryko-henealohichne doslidzhennia. Lviv: Prostir-M, 2017.

Sochaniewicz, Kazimierz. "Rozwody na Rusi Halickiej w XV i XVI wieku”. Pamiętnik Historyczno-Prawny 7 (1929), 3: 1-62. 
Szaraniewicz, Izydor. Rys wewnętrznych stosunków Galicyi wschodniej w drugiej połowie XV wieku. Lwów: W drukarni Instytutu Stauropigiańskiego, 1869.

Wolff, Juzef. Kniaziowie litewsko-ruscy od końca czternastego wieku. Warszawa: Drukiem J. Filipowicza, 1895.

Voronchuk, Iryna. Rodovody volynskoi shliakhty XVI - pershoi polovyny XVII st. (rekonstruktsiia rodynnykh struktur: metodolohiia, metodyka, dzherela). Kyiv: Vyshcha shkola, 2009.

Voronchuk, Iryna. Naselennia Volyni v XVI-pershii polovyni XVII st.: rodyna, domohospodarstvo, demohrafichni chynnyky. Kyiv: Feniks, 2012.

Voronchuk, Iryna. "Ukrainska shliakhetska rodyna rannomodernoi doby u vnutrishnikh zviazkakh i stosunkakh: batky i dity". Ukraina Lithuanica: studii z istorii Velykoho kniazivstva Lytovskoho 4 (2017): 189-205.

\title{
Volhynian Court Books as a Source for Studying the History of the Ukrainian Noble (Szlachta) Family in the $16^{\text {th }}$ and $17^{\text {th }}$ Centuries
}

\begin{abstract}
Summary
At all times, for every person, the family represents the closest social group, and hence, family ties and relationships comprise the most important aspect of personal life. The history of private life, including family life has attracted close attention in historical research worldwide. However, in Ukrainian historiography, it remains on the periphery of historical research and a wide spectrum of issues regarding the history of the family have not yet been explored. Using the anthropological approach, reconstructive and comparative methods, and the method of critical analysis of documentary sources, this article discusses the approach to studying the history of the Ukrainian family. The heterogeneity in the historical evolution of different regions requires us to limit our attention in time and space, as it is rather difficult, if not impossible, to study the history of family relationships in the whole of Ukraine. In this article, we focus on the Volhynian family in early modern times.

It is well understood that the study of the history of the family requires numerous, extensive and comprehensive sources. For the history of the early modern Volhynian family, such relatively well-preserved documents are recorded in judicial and administrative books, the most relevant of which are the books of castle and land courts. Created on the model of the Polish court system, in the Volhynian voivodeship, castle and land courts were established by the Second Lithuanian Statute of 1566 and existed until the middle of the $19^{\text {th }}$ century. In the course of centuries, court books had a rather difficult history and many of them have been lost. Yet, the Central State Historical Archives of Ukraine in Kyiv presently retain 2,119 judicial and administrative books, of which 643 are the castle and land court books of early modern Volhynia. For a long time, court book records
\end{abstract}


remained largely overlooked by Ukrainian scholars because the study of private and family life in the pre-Soviet period was not among research priorities. This article documents and emphasizes the importance and significance of castle and land court books for studying the history of the early modern Ukrainian family.

An important feature of castle and land courts was that, in addition to judicial functions, they also carried out functions of notary institutions, i.e., they notarized documents of private property rights. Most agreements and records were of a financial or business nature and were settled within a family or amongst relatives. Among them are marriage contracts, dowry insurance records, gift deeds and testaments that contain detailed information on married couples and their offspring, and hence provide important data for the reconstruction of contemporary families. Purchase and sale agreements (venditio, emptio, resignatio), exchange agreements (commutatio), pledge records (obligatio), records on the division of estates among relatives (ad attentandam exdivisionum), and protests against unfair property distribution or its illicit appropriation (protestationes) are the most valuable in establishing extended family (kin) relations. Thus, a significant number of court records contain direct and explicit information on lineal and collateral consanguinity, marriage ties, and relationships among blood and close relatives. Nevertheless, the available data require verification by way of documentary research and critical analysis.

The importance of court books for genealogical research has been demonstrated by prominent Polish scholars who laid the foundations of Ukrainian genealogy and constructed family trees of Ukrainian szlachta. However, the significance of court books is not confined to the reconstruction of family structures. Their importance is also in preserving and providing information on existing marriage practices and intra-family relations. In Ukrainian historiography, Orest Levitskii was among the first to rely on court books to study the history of the family. The renowned Polish scholars Aleksander Jabłonowki and Juliusz Bardach explored family relationships in $16^{\text {th }}$ - and $17^{\text {th }}$-century Volhynia. Thereafter, research on the history of the Ukrainian family stalled. Therefore, in Ukrainian historiography, the history of the family, particularly in early modern times, remains a rather novel strand of research - research that requires a thorough in-depth analysis of castle and land court books that are essentially the only documentary source on this subject.

Recently, inspired by the advances in academic literature including those by Polish scholars, Ukrainian historians have engaged in studying the history of the early modern Ukrainian family. Based on the court records, family trees of the ordinary Volhynian szlachta from the $15^{\text {th }}$ to the $17^{\text {th }}$ centuries have been constructed, which allows us to estimate various demographic statistics, such as the average birth rate and the number of children, and to characterize marriage and it is determinants, and the structure and features of family organization. The results reveal that the model of the early modern Ukrainian family differed from the contemporaneous Polish one. According to the conclusions of Polish historians and demographers, Polish society practiced the custom 
of late marriages. A comparative analysis of Ukrainian laws, in particular of the Statutes of 1529,1566 , and 1588, and social practices documented in court books reveals that, in contrast, early age marriages prevailed in Ukrainian lands. The re-constructed family trees of Volhynian szlachta testify to relatively high birth rates among Ukrainan szlachta that is also consistent with the early-age marriage norm. It should be noted that a complete register of early modern szlachta families from the $15^{\text {th }}$ to the $17^{\text {th }}$ centuries has not yet been compiled by Ukrainian historians, which hinders the estimation of the overall szlachta population.

A careful critical analysis of court book documents questions some of the propositions advanced in the earlier literature on the position of women in Ukrainian society at that time. We find that the prevalent patriarchal social system with unlimited parental authority inhibited not only girls and women but also young men from exercising their free will in choosing marriage partners. Marriage was of a totally pragmatic nature, initiated by parents and, first and foremost, it served the economic and social interests of the whole family. The existing notion of ideal marital and, more generally, family relationships that was drawn upon dowry insurance records also requires critical re-examination. Numerous records show that women were often coerced by their husbands to register gift deeds to the benefit of their husbands, who in such a manner tried to appropriate their wives' real estate property. The documents also reveal the brutal treatment of women by their husbands in everyday life.

A significant number of records illustrate the relationships between parents and children, documenting their emotional complexity and diversity: from mutual understanding, love and respect to manifestations of disrespect, brutality and the cruelty of men towards women, children and elders. While Polish historiography has been engaged in the active ongoing research of family relationships, in Ukrainian historiography, such research has only just started. The analysis of contemporary Polish-Ukrainian marriage ties, the information on which is also contained in the $16^{\text {th }}$ - and $17^{\text {th }}$-century court records, might appeal to both Polish and Ukrainian scholars.

Overall, our analysis shows that Volhynian castle and land court books are an important systematic source for the comprehensive study of the history of the early modern Ukrainian family. They provide a significant amount of data and information that help reconstruct family structures, establish kin relations, and characterize family interactions. Court books are an invaluable source as they contain extensive, comprehensive and numerous records on the szlachta, from its highest ranks to its lowest. This allows us to understand similarities and identify differences in the marriages and family characteristics of the wealthy and poor strata of szlachta. Documents from the castle and land court books shed light not only on the degree of kinship, filiation and family ties but also on intra- and inter-family relationships, the system of values, mentality and demographic behaviour of the people in that period. The history of the early modern Ukrainian family that can be reconstructed via a thorough analysis of court books allows us to see a person 
in a family circle, learn about norms of conduct, intra-family relations, human emotions and feelings.

\section{Wołyńskie księgi sądowe jako źródło do badań nad historią ukraińskiej rodziny szlacheckiej w XVI-XVII stuleciu}

\section{Streszczenie}

We wszystkich czasach, dla każdej osoby, rodzina stanowi najbliższą grupę społeczną i dlatego też więzy i relacje rodzinne mieszczą w sobie najważniejsze aspekty życia prywatnego. Historia życia prywatnego, włączając życie rodzinne, jest przedmiotem zainteresowania światowych badań historycznych, jednakże w ukraińskiej historiografii pozostaje na peryferiach badań, a zagadnienia związane $\mathrm{z}$ historią rodziny nie są jeszcze przebadane. Wykorzystując podejście antropologiczne, metody rekonstrukcyjne i porównawcze oraz metodę krytycznej analizy źródłowej, w artykule poruszono zagadnienie badań nad historią ukraińskiej rodziny. Różnorodność poszczególnych regionów pod względem historycznego rozwoju sprawia, że trudno, jeśli w ogóle to możliwe, prowadzić badania nad historią stosunków rodzinnych na obszarze całej Ukrainy. W artykule skoncentrowano uwagę na wołyńskiej rodzinie w epoce wczesnonowożytnej.

Powszechnie wiadomo, że badanie historii rodziny wymaga dostępu do licznych, obszernych i wszechstronnych źródeł. W historii wczesnonowożytnej rodziny wołyńskiej takie stosunkowo dobrze zachowane dokumenty zarejestrowane są w księgach sądowych i administracyjnych, z których najbardziej istotne są księgi sądów grodzkich i ziemskich. Utworzone zgodnie z polskim systemem sądownictwa sądy grodzkie i ziemskie w województwie wołyńskim zostały ustanowione na mocy Drugiego Statutu Litewskiego z 1566 roku i istniały do połowy XIX wieku. W ciągu burzliwej historii Ukrainy wiele ksiąg sądowych zostało utraconych. Obecnie Państwowe Archiwum Historyczne Ukrainy w Kijowie przechowuje 2119 ksiąg sądowych i administracyjnych, z których 643 to księgi grodzkie i ziemskie wczesnonowożytnego Wołynia. Przez długi czas księgi sądowe były w dużej mierze pomijane przez ukraińskich uczonych, ponieważ badanie życia prywatnego i rodzinnego okresu wczesnonowożytnego nie należało do priorytetów badawczych. Niniejszy artykuł dokumentuje i podkreśla wagę oraz znaczenie ksiąg sądów grodzkich i ziemskich dla badania historii wczesnonowożytnej rodziny ukraińskiej.

Ważną cechą sądów grodzkich i ziemskich było to, że oprócz funkcji sądowniczych pełniły one także funkcje notarialne, tj. poświadczały notarialnie dokumenty dotyczące praw własności prywatnej. Większość umów i zapisów miała charakter finansowy lub gospodarczy i była regulowana w obrębie rodziny lub wśród krewnych. Wśród nich są umowy małżeńskie, dokumenty zabezpieczające sprawy posagów, akty darowizn i testamenty, które zawierają szczegółowe informacje na temat małżeństw i ich potomstwa, a zatem dostarczają ważnych danych do rekonstrukcji ówczesnych rodzin. Umowy 
kupna i sprzedaży (venditio, emptio, resignatio), umowy wymiany (commutatio), rejestry zastawów (obligatio), zapisy o podziale majątku między krewnych (ad attentandam exdivisionum) oraz protesty przeciwko nieuczciwej dystrybucji nieruchomości lub jej nielegalnemu przywłaszczeniu (protestationes) są najbardziej wartościowe w ustalaniu relacji rodzinnych. Znaczna liczba akt sądowych zawiera więc bezpośrednie i wyraźne informacje na temat pokrewieństwa w linii prostej i bocznej, więzi małżeńskich i związków między spokrewnionymi i bliskimi krewnymi. Dostępne dane wymagają jednak weryfikacji badanych dokumentów i ich krytycznej analizy.

Znaczenie ksiąg sądowych dla badań genealogicznych zostało ukazane przez wybitnych polskich uczonych, którzy stworzyli podwaliny ukraińskiej genealogii i sporządzili drzewa genealogiczne ukraińskiej szlachty. Nie ogranicza się ono jednak do rekonstrukcji struktur rodzinnych. Znaczenie tych ksiąg polega na tym, że przechowują one i dostarczają informacje o istniejących praktykach małżeńskich i stosunkach wewnątrz rodziny. W ukraińskiej historiografii Orest Lewicki był jednym z pierwszych, który oparł się na księgach sądowych, badając historię rodziny. Znani polscy uczeni, Aleksander Jabłonowski i Juliusz Bardach, studiowali relacje rodzinne na Wołyniu w XVI-XVII stuleciu. Następnie badania nad historią ukraińskiej rodziny utknęły w martwym punkcie. Dlatego w ukraińskiej historiografii historia rodziny, zwłaszcza wczesnych czasów nowożytnych, pozostaje raczej nowym wątkiem badań - badań, które wymagają gruntownej, dogłębnej analizy grodzkich i ziemskich ksiąg sądowych, będących zasadniczo jedynym źródłem na jej temat.

Zainspirowani rozwojem stanu badań, w tym polskich, ukraińscy historycy zajęli się niedawno badaniem historii wczesnonowożytnej rodziny ukraińskiej. Na podstawie zapisów sądowych skonstruowano drzewa genealogiczne zwykłej szlachty wołyńskiej z XV-XVII wieku, co pozwala oszacować różne statystyki demograficzne, takie jak średnia liczba urodzeń i liczba dzieci, oraz scharakteryzować małżeństwo i determinanty jego zawierania oraz strukturę i cechy funkcjonowania rodziny. Uzyskane wyniki pokazują, że model wczesnonowożytnej rodziny ukraińskiej różnił się od ówczesnego polskiego. Zgodnie z wnioskami polskich historyków i demografów polskie społeczeństwo praktykowało zwyczaj późnych małżeństw. Analiza porównawcza ukraińskich praw, w szczególności Statutów z lat 1529, 1566 i 1588, oraz praktyk społecznych udokumentowanych w księgach sądowych pokazuje, że na obszarach Ukrainy przeważały małżeństwa zawierane we wczesnym wieku. Zrekonstruowane drzewa genealogiczne szlachty wołyńskiej świadczą o stosunkowo wysokim wskaźniku urodzeń wśród szlachty ukraińskiej, co jest również zgodne z normą małżeństwa we wczesnym wieku. Należy zauważyć, że kompletny rejestr wczesnonowożytnych rodzin szlacheckich z XV-XVII wieku nie został jeszcze opracowany przez ukraińskich historyków, co utrudnia oszacowanie ogólnej populacji szlachty.

Uważna krytyczna analiza dokumentów sądowych kwestionuje niektóre wnioski wysunięte we wcześniejszej literaturze na temat pozycji kobiety w ówczesnym społeczeństwie ukraińskim. Powszechny patriarchalny system społeczny z nieograniczoną 
władzą rodzicielską utrudniał nie tylko dziewczętom i kobietom, ale także młodym mężczyznom dobrowolny wybór partnerów małżeńskich. Małżeństwo miało charakter całkowicie pragmatyczny, inicjowane było przez rodziców i służyło przede wszystkim interesom ekonomicznym i społecznym całej rodziny. Istniejące pojęcie idealnego związku małżeńskiego i, bardziej ogólnie, relacji rodzinnych, które szkicują niejako rejestry zabezpieczeń posagowych, również wymaga krytycznej ponownej oceny. Liczne zapisy pokazują, że kobiety były często zmuszane do rejestrowania aktów darowizny na rzecz swoich mężów, którzy w ten sposób próbowali przywłaszczyć sobie nieruchomości swoich żon. Dokumenty ujawniają także brutalne traktowanie kobiet przez ich mężów.

Znaczna liczba zapisów ilustruje relacje między rodzicami i dziećmi, dokumentując ich złożoność emocjonalną i różnorodność: od wzajemnego zrozumienia, miłości i szacunku do przejawów braku szacunku, brutalności i okrucieństwa mężczyzn wobec kobiet, dzieci i starszych. Podczas gdy polska historiografia była zaangażowana w aktywne badania nad relacjami rodzinnymi, w ukraińskiej takie badania właśnie się rozpoczęły. Analiza ówczesnych polsko-ukraińskich więzi małżeńskich, o których informacje zawarte są również w aktach sądowych XVI-XVII wieku, może „przemawiać” zarówno do polskich, jak i ukraińskich uczonych.

Wołyńskie księgi ziemskie i grodzkie są ważnym uporządkowanym źródłem wszechstronnych badań nad historią wczesnonowożytnej rodziny ukraińskiej. Dostarczają znacznej ilości danych i informacji pomocnych przy rekonstrukcji struktur rodzinnych, ustalaniu relacji międzyludzkich i charakterystyce interakcji rodzinnych. Księgi sądowe są nieocenionym źródłem, ponieważ zawierają obszerne, wszechstronne i liczne zapisy dotyczące szlachty, od najwyższych do najniższych warstw. Pozwala nam to zrozumieć podobieństwa i zidentyfikować różnice w małżeństwach i cechach rodzin bogatych i biednych warstw szlachty. Dokumenty ksiąg sądów grodzkich i ziemskich rzucają światło nie tylko na stopień pokrewieństwa, filiacji i więzi rodzinnych, ale także na relacje wewnątrzrodzinne i między rodzinami, system wartości, mentalność i zachowania demograficzne w tym okresie. Historia wczesnonowożytnej rodziny ukraińskiej, którą można zrekonstruować poprzez dokładną analizę ksiąg sądowych, pozwala zobaczyć osobę w kręgu rodzinnym, poznać normy postępowania, relacje wewnątrz rodziny, ludzkie emocje i uczucia. 